孤立性小腸転移にて小腸閉塞をきたした胸部上部食道癌の 1 例

\author{
東海大学大磯病院外科, 東海大学医学部外科* \\ 田島隆行向井正哉檜友也 \\ 大谷泰雄中㥓久雄幕内博 康*
}

食道癌の小腸転移は稀である. 今回，食道扁平上皮癌の小腸転移により腸閉塞症をき たし手術，後日，頸胸部食道に狭囬をきたしステントインステントに治療した 1 例を経 験したので報告する. 症例は62歳の男性で, 踖下時のつかえ感で発症, 胸部上部食道癌 (Ut)に 3 型食道癌を認めた。多発性肺転移と縦隔りンパ節転移を認め stage IVb と誩断 し化学療法を施行した. 外来経過中の 4 力月後に絽り返す嘔吐にて外来受診し腸閉塞の ため緊急入院. 虫垂切除術の既往があるため凅着による腸閉塞と診断し, 腹腔鏡下に癒 着剩離を施行したところ小腸に腫瘍性病変を認め開腹小腸切除術を施行し, 食道癌の小 腸転移と款断された。その後抢こった，頸胸部食道の狭窄に対してはステントインステ ントにて治療した症例を経験したので文献考察を加え報告する.

事引用語：胸部上部食道癌, 小腸転移, ステントインステント

緒言

腹腔外藏器からの小腸転移は比較的稀で食道扁平上 皮癌の小腸転移の報告は少ない. 剖検例の食道癌他臓 器転移の検討は，食道癌 1,132 例中肺転移459例 (40.5 $\%)$, 肝転移 328 例 $(29.0 \%)$ が多く胃以外の消化管転 移は36例 $(3.2 \%)$ と少ない1). 切除不能食道扁平上皮 癌の加療中に小腸転移により腸閉塞をきたし切除。そ の後, 頸部食道の狭窄にステントインステントを挿入 した症例を経験したので報告する。

\section{症例}

症例：62歳, 男性.

主訴：腹痛, 嘔気, 嘔吐.

既往歴：虫垂炎にて手術 (18歳)。脳梗塞 (59歳).

現病歴：平成13年 1 月頃より胸部のつか元感のため

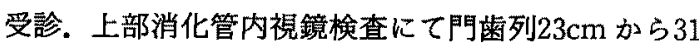
$\mathrm{cm} の 3$ 型進行食道癌と多発性肺転移と診断し入院の 上，化学療法 (FP 療法)を 3 クール施行した。食道癌 取扱い規約)の効果判定で主病栄は PD，肺転移单は NCであった。そその後, 外来経過中に腸閉塞で緊急入院 となった。

2004 年 7 月 14 日受付 2004 年 9 月 10 日採用

〈所属施設住所〉

T259-0198 神奈川県中郡大磯町月京21-1
入院時現症：身長 $163 \mathrm{~cm}$, 体重 $52 \mathrm{~kg}$, 血圧 $122 / 62$ $\mathrm{mmHg}$, 脈拍 $72 /$ 分整, 眼铪結膜に軽度の貧血があり腹 部は膨満し压痛があった。

入院時血液検查所見：異常所見はなかった。

入院時腹部単純 $\mathbf{X}$ 線写真：拡張した小腸ガス像と ni veau を認めた。

イレウスチューブ造影検查：右下腹部の小腸に狭窄 を認めた（図 1)。

以上から虫垂炎術後流着性腸閉塞の診断にて平成 13 年 7 月に手術を施行した。

手術所見：腹腔鏡下に検索したところ回盲部から70 $\mathrm{cm}$ の部位に腫瘍性病変を認めたために下腹部正中切 開の開腹手術に移行した。開腹時小腸間膜に白色の小 結節を認め迅速病理検查にて食道癌の腹腔内播種と診 断した。獏窄部はこの一カ所で小腸部分切除術を施行 した.

摘出標本肉眼所見：全周性の 2 型の直径 $25 \times 31 \mathrm{~mm}$ の硬い腫瘍であった（図 2 )。

病理組織学的所見：扁平上皮癌が粘膜下を中心に充 実性增殖 (図 3 a) し墏膜は保たれ(図 3 b), 食道癌 の小腸転移と診断した。

術後経過：術後 7 日目より経口摄取を開始. ₹の後, $\mathrm{FP}$ 療法（4クール目）を施行し退院.

同年10月になり唾液を吐くようになり入院.上部消 


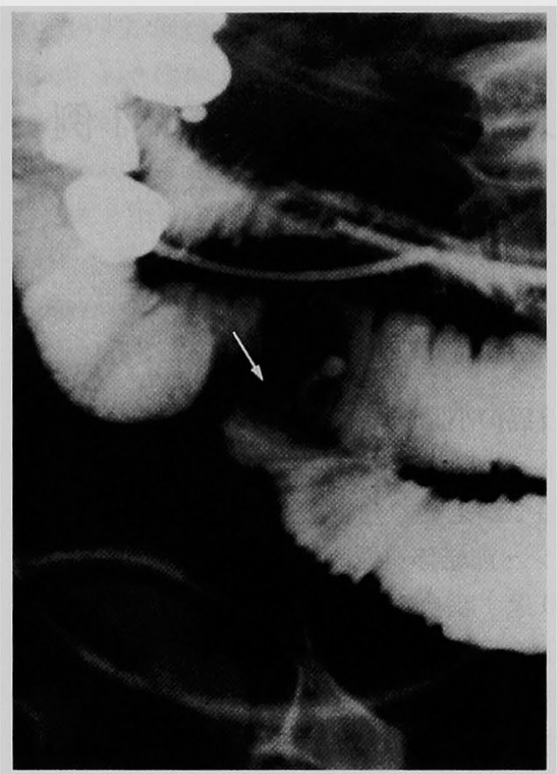

図 1 イレウスチューフ造影検査 : 右下腹 部に狭窄像を認める。

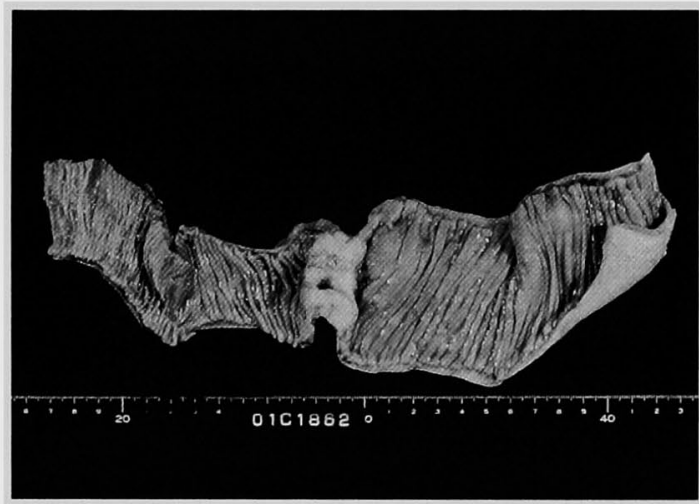

図 2 切除組織標本 : 小腸を閉塞する腫瘍性病変を認め る.

化管造影検查を施行し胸部中部に狭窄を認め, 同部に 長さ $7 \mathrm{~cm}$ のステントを㨀入し退院となった.

翌年 4 月になり再び唾液を嘔吐するため上部消化管 造影・内視鏡検查を施行しステントの口側に全周性の 狭窄を認め入院.内視鏡下に胸骨上縁から $15 \mathrm{~mm}$ の部 位をステントロ側端としてステントインステントを挿 入 (図 4 ). 挿入後は疼痛・嶼下困難や気道系合併症を 起こすことなく食事を再開出来たが約 2 カ月後, 肺の 癌性リンパ管症にて永眠された。
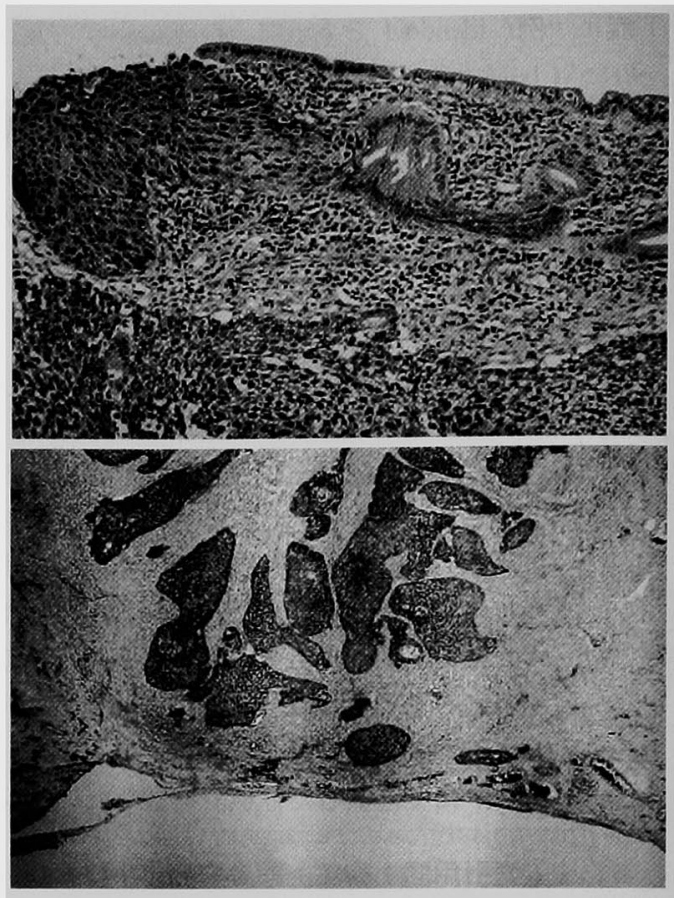

図 3 病理組織所見：粘膜下を中心に扁平上皮癌が充 実性増殖をしている（a），槳膜面の断裂は認められ なかった（b).

$\frac{a}{b}$

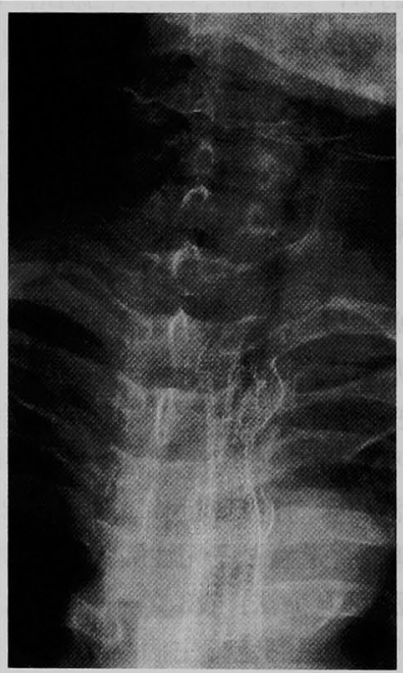

図 4 ステントインステント後 胸部レントゲン写真：胸骨上 縁から $15 \mathrm{~mm}$ の部位をステン トロ側端としてステントイン ステントを挿入した。 
表 1 食道癌の小腸転移の報告例

\begin{tabular}{|c|c|c|c|c|c|c|c|c|}
\hline & \multirow[t]{2}{*}{ 性别 } & \multirow[t]{2}{*}{ 年酷 } & \multicolumn{4}{|l|}{ 主病巣 } & \multicolumn{2}{|l|}{ 小腸転移緹 } \\
\hline & & & 部位 & 組織型 & 術前診断 & 治療 & 治療 & 病巣数 \\
\hline 1. (Reference 10 ) & 男性 & 65 & $\mathrm{Lt}$ & SCC & 小晹転移 & 手術 & 開廈切除 & 1 \\
\hline 2. (Reference 11) & 女性 & 55 & $\mathrm{Mt}$ & Undiff-Ca & 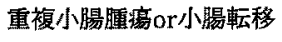 & 手䔎＋化学 & 開䧗切除 & 1 \\
\hline 3. (Reference 12) & 男性 & 56 & $\mathrm{Mt}$ & $\mathrm{SCC}$ & 小腸転移 & 手術十化学＋放治 & 開腹切除 & 1 \\
\hline 4. (Reference 13) & 男性 & 62 & $\mathrm{Mt} \sim \mathrm{Lt}$ & $\mathrm{SCC}$ & 重複小腸腫㻛 & 化学+放治 & 腹腔鏡切除 & 2 \\
\hline 5. (Reference 14) & 男性 & 63 & $\mathrm{Lt}$ & $\mathrm{SCC}$ & 不明 & 空腸瘦 & 開腹切除 & 1 \\
\hline 6. (our case) & 男性 & 62 & $\mathrm{Mt} \sim \mathrm{Ut}$ & SCC & 術後维着による腸閉塞 & 化学 & 開腹切除 & 1 \\
\hline
\end{tabular}

\section{考 察}

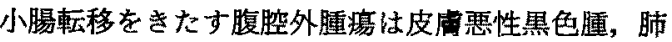
癌, 乳癌, 悪性黑色腫以外の皮病癌, 胎児性筋肉腫,

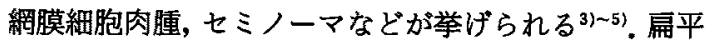

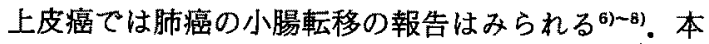
症例は胸部 CT 検查にて多発性の肺内病変を認めた が, 臨床経過と画像診断から転移性肺癌と診断. 皮膚 癌などの病変も認めなかったことから食道扁平上皮癌 の小腸転移と考之た。食道癌の小腸転移例は，1987年 から2003年までに㭘索しえたかぎりでは剖検(例19)を 除くと，本症例で 6 例年 14)である(表 1 ).

食道癌小腸転移について論文記載の明らかな症例か ら検討してみると，年齢は 56 ～65歳で 6 例とも進行食 道癌で 5 例は扁平上皮癌，1例は末分化癌. 3 例は食 道切除例が施行. 転移巣は空腸から回腸まで及んでい た. 転移個数は 2 個が 1 例あり，残り 5 例は全て単発 であった。転移性小腸腫場の転移形式は 1) 連続浸潤,

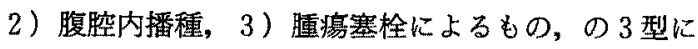
分類され腫汮塞栓による転移として多い腫漡は悪性黒 色腫, 次いで乳癌, 肺癌と報告されている ${ }^{15)}$. 本症例は 腸間膜上に小結節を認め腹膜播種と蹘断されている が、イレウスを呈した腫湯部の墏膜の破壊像はなく腫 富塞栓による転移と推察した。

術前診断は転移性小腸腫湟と診断されたのは 2 例, 原発性小腸腫喤 2 例（内 1 例は小腸転移も疑われた）, 不明 1 例であった。臨床症状は穿孔・閉塞・出血など の急性腹症としての発症が多く緊急に外科的処置を要 する例が多いことが特徴的である ${ }^{11)}$.しかし，自験例で は腸閉塞症状で発症したが虫垂炎術後のため癒着性イ レウスと診断した。食道癌の小腸転移は稀であるが, 外科臨床上注意すべき点と考えられた。

腹腔鏡下の手術をしたが転移性小腸腫瑒・腹膜播種 のため開腹手術へ移行した．大腸腫場に対する腹腔鏡 下手術と開腹術との比較は, 前者㹥後者に比し出血量
は少ないが術後合併症の発生率は同等, 術後の経口摄 取開始時期や入院期間が短いと腹腔鏡下手術の有用性 が証明されている ${ }^{16 \sim 18)}$. しかし, 腹腔鏡のために腹壁 に挿入するトロッカーの部位の再発（port site implantation ; PSI) が発生しており，1994年までは21一 $29 \%$ と高率の PSI の報告 ${ }^{19200}$ があったが，以後の報 告 ${ }^{171182121}$ では $0-5 \%$ 前後と少なく, 手術の適応や手 技が向上していると考えられる. 本症例では腹膜播種 もありPSI を㲘念し開腹手術へ移行した。

食道癌に対するステンント挿入は低侵襲で有用性は評 価され，口側端が胸骨上緑より $2 \mathrm{~cm}$ 以内に挿入でき れば, 疼痛や気道系合併症を起こすことなく経口摄取 は可能であるとの報告もあり胸骨上粶約 $1.5 \mathrm{~cm} に 2$ 回目のステントの口側端を栔め条件を満たしているも のと思われた。

本稿の要旨は第65回日本臨床外科学会総会一般演題 - 示 説（2003年11月14日，福岡）において発表した。

$$
\text { 文献 }
$$

1）山下延男：剖検データに基づいた食道癌の転移経 路に関する統計解析一，日癌治療会誌 $14: 1146$ $-1149,1970$

2）日本食道疾患研究会編：食道癌取扱い規約. 改訂 第 9 版，金原出版，東京，1999

3) Richie RE, Reynolds VH, Sawyers JL: Tumor metastases to the small bowel from extraabdominal sites. South Med J 66:1383-1387, 1973

4) De Castro CA, Dockerty MB, Mayo CW: Metastatic tumor of the small intestines. Surg Gynecol Obstet 105: 159-165, 1957

5) Macbeth WA, Gwynne JF: Tumours of the small bowel. Aust NZJ Surg 38 : 206-215, 1969

6）山田 忍，藤本泰久，高島 勉他：腸閉塞をきた した肺癌小腸転移の1 例. 日腹部救急医会誌 $19: 373-377,1999$

7）菅原 元, 藤岡 進, 加藤煡司他：転移性小腸腫 
痗による腸閉塞を発症機序とする原発性肺癌の1

例。日腹部救急医会誌 $19: 69-73,1999$

8）小林 峪, 寺崎正起, 岡本恭和他：びまん浸潤型 小腸転移をきたした原発性肺癌の 1 例、癌の臨 $46: 933-936,2000$

9) Williams DJ : Metastatic oesophageal squamous cell carcinoma in a small bowel neurofibroma. Jap J surg 18:110-113, 1988

10) Wang M, Patel J, Casey TT, et al : Metastatic squamous cell carcinoma from the esophagus occurring as small bowel obstruction. South Med J 78:884-886, 1985

11）津秦建治, 石本喜和男, 山本異二他：空腸転移を 来たした食道未分化癌の 1 治験例と転移性小腸腫 瘍の本邦報告例の検討. 日臨外医会誌 $45: 1313$ $-1319,1984$

12) Yamada $T$, Yagi S, Tatsuzawa $Y$, et al : Small intestinal metastasis from esophageal carcinoma associated with small intestine obstruction : Report of a case. Surg Today 26:800802,1996

13）中村隆俊, 大谷阙正, 三富弘之他：腹腔鏡補助下 に手術した食道癌小腸転移によるイレウスの1 例。日消内視鏡会誌 $44: 755-760,2002$

14）下沖収, 馬場祐康, 吉田徹他：小腸転移をき たした食道扁平上皮癌の 1 例。日消外会誌 36 ： $1493-1497,2003$
15) Meyers MA, McSweeney J:Secondary neoplasms of the bowel. Radiology $105: 1-11$, 1972

16) Lacy AM, Garcia-Valdecasas JC, Piqe JM, et al: Short-term outcome analysis of a randomized study comparing laparoscopic vs open colectomy for colon cancer. Surg Endosc 9 : $1101-1105,1995$

17）斉田芳久, 炭山嘉伸, 長尾二郎他：腹腔鏡下大腸 切除術の術後経過一従来の開腹術に比較して一。 日本大腸肛門病会誌 $49: 1087-1092,1996$

18) Milsom JW, Bohm B, Hammerhofer KA, et al : A Prospective, randomized trial comparing laparoscopic versus conventional techniques in colorectal cancer surgery: A preliminary report. J Am Coll Surg 187 : 46-57, 1998

19) Berends FJ, Kazemier G, Bnjer HJ, et al : Subcutaneous metastases after laparoscopic colectomy. Lancet $58: 344,1994$

20) Cirocco WC, Schwartzmann A, Golub RW: Abdominal wall recurrence after laparoscopic colectomy for colon cancer. Surgery 116:842 $-846,1994$

21) Wexner SD, Cohen SM : Port-site metastases after laparoscopic colorectal surgery for cure of malignancy. Br J Surg $82: 295-298,1995$

\title{
A CASE OF UT ESOPHAGEAL CANCER CAUSING OBSTRUCTION OF THE SMALL INTESTINE DUE TO SOLITARY SMALL INTESTINAL METASTASIS
}

\author{
Takayuki TAJIMA, Masaya MUKAI, Tomoya HINOKI, \\ Yasuo OTANI, Hisao NAKASAKI and Hiroyasu MAKUUCHI* \\ Department of Surgery, Tokai University Oiso Hospital \\ * Department of Surgery, Tokai University School of Medicine
}

Esophageal cancer rarely metastasizes to the small intestine. We present a case of squamous cell carcinoma of the esophagus causing intestinal obstruction due to small intestinal metastasis, in which stricture of the cervical esophagus was treated by insertion of a stainless stent.

A 62-year-old man presented with difficulty in swallowing, and was found to have esophageal cancer type 3 in the intrathoracic upper third of the esophagus (Ut). Multiple pulmonary and mediastinal lymph node metastases were identified. We diagnosed the case as esophageal cancer in stage IVb and conducted chemotherapy. Four months later he was seen at the outpatient clinic because of repeated bouts of vomiting and was emergently admitted to the hospital with a diagnosis of intestinal obstruction. Because of his previous history of undergoing appendectomy, he was diagnosed as having intestinal obstruction due to adhesions and placed an ileus tube. Laparoscopic adhesiotomy disclosed a tumorous lesion in the small intestine, so that small bowel resection under laparotomy was performed and small bowel metastasis of esophageal cancer was diagnosed. Thereafter a stainless stent was inserted into the stricture of the cervical esophagus. This paper deals with the case with a review of the literature. 